\title{
ARTEFAK MANIK-MANIK DALAM PERSPEKTIF ARKEOLOGI (Beads Artifact on Archaeology Perspective)
}

\section{Nasruddln}

Pusat Penelitian Arkeologi Nasional Jl. Raya Condet Pejaten No.4, Pasar Minggu, Jakarta. Telp. (021) 7988171, e-mail: undink.anaugi@gmail.com

INFO ARTIKEL

\section{Histori artikel}

Diterima: 3 Februari 2016

Direvisi: 2 Maret 2016

Disetujui: 17 Mei 2016

\section{Keywords: \\ History, \\ distribution, \\ variability}

\author{
Kata kunci: \\ sojarah, \\ distribusi, \\ variabilitas
}

\begin{abstract}
Knowledge about objects beads as cultural works, mainly because it is used for clothing and jewelry of the human body. Since when made and used, is a question that requires a search through research. Small objects is one of the many artifacts of human cultural objects can be studied through the field of archeology. Beads of all types, materials and colors, thought to have been present to accompany the man, from prehistoric times to the modem era. From archaeological research report states that the findings bead old age, among other things found in the cave sites such as Sulawesi, Mangkulirang East Kutai, Kalimantan and East Java and the surrounding environment is in the karst region. This research aims to understand the early history of the presence of beads for human life is based on archaeological evidence that is already known. Through the identification of artifacts beads diversity, ranging from the type, shape up the material element, it can put forward a variety of beads found in Indonesia starting from stone material, glass, metal to organic materials. Beads that can be identified include stone beads, glass, and only a small amount of organic materials and metals. Beads, mainly dominated glass beads, particularly the type of monochrome and polychrome. In connection with the scientific effort, the methods and ways of working that are used to understand the data artifacts beads that are completely limited, by using the method; contextual analysis, analysis of typology, analogy, and interpretation.
\end{abstract}

\section{ABSTRAK}

Pengetahuan mengenai benda manik-manik sebagai karya budaya, terutama karena digunakan untuk pakaian dan perhiasan tubuh manusia. Sejak kapan dibuat dan dipakai, adalah suatu pertanyaan yang memerlukan penelusuran melalui penelitian. Benda kecil ini merupakan salah satu artefak dari sekian banyak benda budaya manusia yang dapat dikaji melalui bidang arkeologi. Manik-manik dengan berbagai jenis, bahan dan warna, diperkirakan telah hadir menemani manusia, sejak masa prasejarah hingga di jaman modern ini. Dari laporan penelitian arkeologi menyebutkan bahwa temuan manik-manik yang berumur tua, antara lain ditemukan di situs-situs gua seperti Sulawesi, Mangkulirang, Kutai Timur, Kalimantan, dan di Jawa Timur dan sekitarnya yang berada di lingkungan kawasan karst. Penulisan ini bertujuan untuk memahami sejarah awal kehadiran manik-manik bagi kehidupan manusia berdasarkan bukti-bukti arkeologi yang sudah diketahui. Melalui identifikasi keragaman artefak manik-manik, mulai dari sisi jenis, bentuk hingga pada unsur bahan, maka dapat dikemukakan aneka ragam manik-manik yang ditemukan di Indonesia mulai dari bahan batu, kaca, logam hingga bahan organik. Manik-manik yang dapat diidentifikasi meliputi manik-manik batu, kaca, dan hanya sedikit jumlahnya daribahan organik dan logam. Manik-manik itu, terutama didominasi manik-manik kaca, khususnya tipe monokrom dan polikrom. Sehubungan dengan upaya ilmiah, maka metode dan cara kerja yang digunakan untuk memahami data artefak manik-manik yang sifatnya serba terbatas itu, yaitu dengan menggunakan metode; analisis kontektual, analisis tipologi, analogi, dan penafsiran. 


\section{PENDAHULUAN}

Salah satu karya budaya manusia yang telah diciptakan sejak masa prasejarah adalah manik-manik. Menurut Encyclopedia Americana (Vol. 3, 1967: 394-395) manik-manik yang dalam bahasa Inggris disebut "beads", berasal dari bahasa Inggris Tengah bede yang artinya "prayer" ("object of worship"; benda untuk memuja). Awalnya manik-manik dikaitkan dengan amulet atau talisman (benda berkekuatan gaib/jimat) sesuatu yang berhubungan dengan religi dan upacara. Manik-manik kemudian juga dihubungkan dengan perdagangan dan telah dikenal sejak jaman prasejarah. Manik-manik dibuat dari berbagai macam bahan seperti batuan, glass, logam, batu koral, gerns (batuan permata), moluska, dan kayu. Manikmanik dibuat dalam berbagai bentuk warna, pola hias, dan ukuran.

Manik-manik sebenarnya sudah lama dikenal di Indonesia, dan hingga kini tetap merupakan salah satu alat hias, alat untuk membangkitkan daya tarik tertentu, yang populer di Indonesia. Sayang sekali, penelitian ilmiah yang serius mengenai posisi dan fungsi manik-manik dalam berbagai suku bangsa di Indonesia ini masih sangat langka, bahkan hampir tidak ada. Oleh karena itu tidak banyak data yang ada pada kita mengenai posisi dan fungsi manik-manik dalam masyarakat di Indonesi

Diketahui bahwa manik-manik kemudian memiliki daya pikat dan pesona yang kuat dalam kehidupan manusia, tidak hanya benda perhiasan, tetapi pada kelompokkelompok masyarakat tertentu digunakan sebagai jimat, sarana upacara ritual, bekal kubur, lambang status sosial pemakainya, dan lainlain. Sebagai obyek keindahan, manik- manik mengundang kekaguman dan sekaligus juga sentuhan-sentuhan daya cipta untuk menghasilkan keindahan baru, baik keindahan murni, maupun keindahan yang menjurus ke perancangan seni terapan atau desain. Berlandaskan kekaguman dan sentuhan-sentuhan artistik-estetik ini manik-manik menjadi punya nilai, yang dapat ditangkap melalui penginderaan mata (nilai visual), dan dapat diukur berdasarkan kaidah-kaidah seni rupa dan desain.

Kehadiran artefak manikmanik sebagai data arkeologi adalah bukti tentang perjalanan panjang dan pencapaian peradaban manusia, diperkirakan telah hadir menemani manusia, sejak masa prasejarah yaitu ketika manusia menempati gua dan ceruk-ceruk alam sebagai tempat tinggal. Asumsi ini terutama didasarkan pada temuan manik-manik jenis moluska dari situs-situs gua dan ceruk. Data tersebut memberikan pengertian bahwa manusia prasejarah (awal Holosen) telah melengkapi dirinya dengan kebutuhan yang sifatnya estetika.

Melalui data manik-manik dapat mengungkapkan dan bercerita banyak tentang berbagai hal antara lain berkenan dengan aspek; penghunian, gagasan, teknologi, perdagangan, perindustrian, apresiasi seni, pengaturan sosial, dan kepercayaan magis-religius. Beberapa laporan penelitian arkeologi menyebutkan bahwa temuan manik-manik tertua berbahan kerang yang ditemukan di sejumlah situs gua, seperti di situs Leang-Leang di Sulawesi ditemukan artefak berbahan moluska, gigi dan taring untuk dipakai sebagai perhiasan kalung. Indikasi tersebut menunjukkan bahwa artefak ini dalam konteks masa prasejarah. Temuan 
sejenis juga dilaporkan dari Situs Gua Mangkulirang, Kutai Timur, Kalimantan, termasuk yang ditemukan di situs guagua di Jawa Timur dan sekitarnya yang berada di lingkungan kawasan karst. Persebaran temuan manik-manik semakin meningkat di era neolitik yang kemungkinan didistribusikan oleh kelompok manusia Austronesia yang bermigrasi ke Nusantara. Pada periode neolitik menjadi titik balik persebaran manik-manik terutama manik-manik kaca sebagai salah satu komoditi perdagangan yang kita kenal dengan istilah silkrood hingga makin meluas memasuki abad sejarah.

Para peneliti yang pernah membahas manik-manik Indonesia antara lain G. Rouffaer, A. W. Nieuwenhuis, W.G.N. van der Sleen, A.H. Th. a Th van der Hoop, J. R. I. Panggabean, dan Sumarah Adhyatman. Sebagian besar dari para penulis ini menguraikan manikmanik berdasarkan bentuk dan pola hiasnya, tanpa menghubungkan dengan ekskavasi arkeologi. Van der Hoop (1932) yang pertama mengupas manik-manik berdasarkan konteks ekskavasi dan analisis kimiawi. Panggabean (1977, 1982, 1983, 1985a, 1985b) menguraikan manik-manik berdasarkan hasil ekskavasi arkeologi di berbagai tempat dan melakukan analisis kimiawi. Sedangkan Sumarah Adhyatman menulis buku tentang Manik-manik di Indonesia (1993) yang menguraikan manik-manik dari Indonesia dan perbandingannya dengan temuan-temuan dari luar Indonesia.

\section{Metode Penelitian}

Arkeolog memiliki kewajiban dan tanggungjawab menganalisis artefak untuk menjelaskan the man behind the artifacts. Arkeolog memiliki keingintahuan tentang perilaku manusia di balik sebuah artefak itu, baik cara membuat, memakai, ataupun membuang artefak. Artefak yang masih berada dalam proses buatpakai-buang itu dikatakan berada dalam konteks sistem. Rentang waktu antara berlangsungnya konteks sistem dengan konteks arkeologi itu bisa mencapai ratusan tahun, ribuan tahun, bahkan jutaan tahun (Schiffer, 1976:27-280).

Data arkeologi memiliki sifat yang serba terbatas, termasuk manik-manik baik, kuantitas maupun kualitas informasi yang dikandungnya. Keterbatasan informasi tersebut disebabkan oleh terbatasnya tingkah laku manusia masa lalu yang terekam lewat artefak, maka untuk menjembatani hal tersebut diperlukan metode dan teknik menggali informasi yang tersirat dalam data artefak. Langkah-langkah yang dapat ditempuh memahami masalah masa lalu dapat ditempuh dengan menggunakan metode; analisis kontekstual, analisis tipologi, analogi, dan penafsiran.

Analisis kontekstual merupakan pengamatan antarhubungan data arkeologi, persebaran, keletakan (provenience), tempat kedudukan (matriks), dan hubungan antar temuan dalam ruang (distribution), dan waktu atau lapisan tanah (stratigrafi layer). Selanjutnya dilakukan analisis tipologis suatu temuan, yaitu pengamatan pada ciri intrinsik, sifat fisik dan atribut-atribut yang melekat pada suatu artefak, meliputi bentuk, ukuran, hiasan, warna, dan tentunya jejak-jejak teknologis (Rouse, 1971: 112, 243).

Bila ingin menelusuri maupun mengetahui masalah cara pembuatan, pemakaian dan pembuangan suatu artefak dalam konteks arkeologi, dapat dilakukan dengan berbagai analisis arkeologi. Tapi lebih lengkap lagi bila 
disertai studi analogi-etnografi. Studi inilah yang kemudian melahirkan satu disiplin ilmu baru, yang lebih bersifat 'ilmu perbatasan' antara arkeologi dan antropologi, yaitu etnoarkeologi. Metode analogi sejarah, etnografi dan eksperimenal terhadap masyarakat yang masih meneruskan atau memproduksi manik-manik secara tradisional merupakan salah satu cara untuk mengetahui teknologi dalam pembuatan manik-manik.

\section{Distribusi Manik-Manik di Indonesia}

Secara umum manik-manik ditemukan hampir di semua tempat di Indonesia walaupun sering tidak dalam konteks penggalian arkeologis. Sejumlah temuan manik-manik yang dikoleksiataupun dipamerkan di museum-museum berasal dari masyarakat, baik sebagai temuan tidak disengaja atau merupakan benda-benda warisan yang kemudian diserahkan ke museum untuk dipelihara. Benda benda hasil hibah atau pun pemberian dan pembelian menjadi sulit untuk diidentifikasi secara kronologis maupun asal usul dan lokasi sebuah benda koleksi. Berbeda halnya dengan temuan yang diperoleh dari penelitian arkeologi dapat diketahui dan dilacak sejumlah informasi masa lalu, karena masih memiliki konteks ruang yang bisa memberikan penjelasan terhadap aspek waktu dan fungsi.

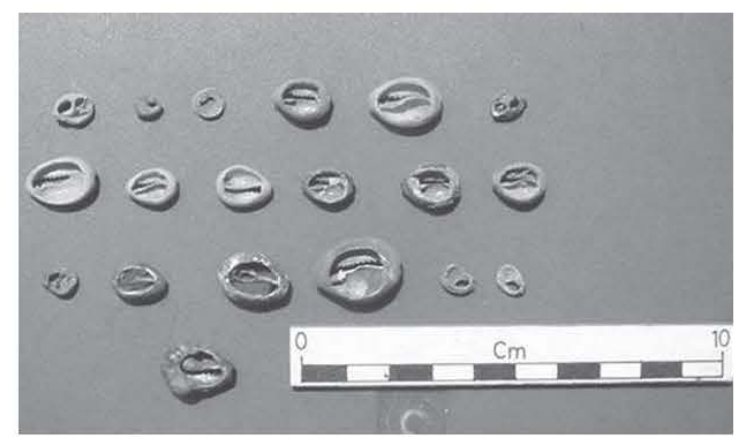

Gambar 1. Manik-manik cowry dari gua Kutai Timur (dokumentasi Nasruddin)
Data manik-manik tertua yang berasal dari periode prasejarah telah banyak dilaporkan melalui penelitian arkeologi, khususnya ditemukan dalam penggalian situs gua-gua hunian antara lain pernah ditemukan di sebuah gua di Sampung berupa manik-manik yang dibuat dari kulit kerang (Soejono, 1984: 285-287). Temuan serupa tentang manik-manik juga dilaporkan dari penelitian kerjasama IndonesiaPerancis (2002-2004) di Kutai Timur, Kalimantan,yang menemukan manikmanik kerang dalam lapisan tanah yang cukup tua (10.000 BP.). Begitu pula di situ gua-gua hunian di Maros Pangkep-Sulawesi berhasil ditemukan benda-benda perhiasan dari kerang, tulang, dan gigi yang difungsikan sebagai manik-manik.

Puncak persebaran manikmanik diketahui terjadi pada fase neolitik, yaitu ketika diaspora Austronesia bermigrasi dari Asia Tenggara yang diduga kuat berasal dari Taiwan pada sekitar $\pm \mathbf{5 0 0 0}$ tahun silam, manusia menyebar ke Nusantara dengan membawa budaya dan teknologi, hingga mulai menetap lebih lama di satu tempat. Pada pase neolitik kemampuan manusia makin meningkat, sehingga pase ini disebut pula dengan revolusi pengetahuan, karena munculnya berbagai inovasi, mulai dari penemuan api, pemukiman, pertanian dan domestikasi, serta seni dan religi. Pada masa neolitik, Nusantara merupakan jalur perdagangan awal dari Asia Daratan menuju Pasifik sehingga mendapat banyak kunjungan dan pengaruh dari luar seperti dari Cina, India, Vietnam, Kamboja, dan Asia Timur Tengah (Siria, Parsi, Iran). Pada masa ini telah diperdagangkan antara lain tekstil, tembikar dan manik-manik. Manikmanik mutisalah dari India ditemukan Sumatra dengan pertanggalan awal 
Masehi. Di situs neolitik di Kelapa Dua (Jakarta) ditemukan manik-manik dari kaca (Panggabean, 1977).

Manik-manik pada masa perundagian ditemukan dalam penggalian di Gunung Wingko, Matesih, Bojonegoro, Besuki, Bondowoso, Solo, Kudus, Madiun. Temuan manikmanik yang ditemukan di situs kubur berasosiasi dengan wadah kubur (peti kubur batu, sarkofagus, dolmen, tempayan, kubur silindrik) atau tanpa wadah (seperti di Gunung Wingko, Plawangan, Gilimanuk). Di Kalimantan Barat tepatnya di Bukit Silindung (Kabupaten Sambas) ditemukan dua nekara yang bertumpuk bertautan antara kaki bagian bawah. Di dalam kedua nekara ini didapatkan beraneka ragam manik-manik yang berbeda bentuk, warna ataupun bahan. Kedua nekara ini sekarang disimpan di Museum Negeri Pontianak. Apakah fungsi manik-manik di dalam dua nekara tersebut belum diketahui dengan pasti karena tidak ditemukan artefak lain. Pada penggalian di Pasir Angin (Bogor) tahun 1976-1978 ditemukan manik-manik dari bahan kaca. Situs Pasir Angin dianggap sebagai situs pemujaan.

Pada penggalian di Plawangan (Rembang) ditemukan manik-manik dalam berbagai bentuk, warna, dan bahan. Manik-manik tersebut ditemukan dalam tempayan, tersebar dalam kotak penggalian dan berada di sekitar kerangka atau menempel pada kerangka manusia. Pendapat Haris Sukendar (1975) tentang temuan di Plawangan adalah bahwa konteks temuan manik-manik yang memiliki korelasi dengan temuan kerangka manusia melandasi asumsi bahwa manik-manik memegang peranan penting sebagai bekal kubur. Asumsi ini diperkuat oleh hasil penelitian di Situs
Gilimanuk Bali dan dalam kubur tanpa wadah di Gilimanuk. Manik-manik yang berasosiasi dengan sarkofagus ditemukan bersama kerangka manusia sebagai hiasan (diletakkan di leher sebagai kalung atau gelang di tangan). Di Gilimanuk manik-manik juga ditemukan bersama rangka manusia, sehingga dapat disimpulkan bahwa manik-manik tersebut berfungsi sebagai bekal kubur (Soejono, 1984). Manik-manik yang digunakan dalam kaitan dengan religi dapat ditemukan di situs-situs kubur atau pemujaan lainnya seperti di Pasemah (Sumatra Selatan), Pasir Angin (Bogor), Gunung Kidul (DI Yogyakarta), Besuki, Plawangan (Rembang), Gilimanuk, Lewoleba (NTT), dan sebagainya. Unsur lain yang dapat dihubungkan dengan manik-manik adalah perhiasan, dan peralatan hidup (Panggabean, 1977).

Sesudah masa prasejarah, yaitu masa Klasik (Hindu-Budha), manik-manik yang ditemukan dan dibuat dari bahan batuan setengah mulia, kuarsa, karnelian, dan kalsedon, kaca, dan tanah liat. Manik-manik hasil ekskavasi di Palembang (Karanganyar dan Kambangulen) berjumlah ribuan terdiri dari manik-manik kaca dan batu. Selain itu, lelehan manik-manik kaca yang belum jadi ditemukan pula di situs di Palembang. Hal ini menarik didiskusikan karena ditemukan dalam satu konteks dengan manik-manik yang sudah jadi, termasuk bahannya. Dengan demikian, disimpulkan bahwa kedua situs tersebut sebagai tempat pembuatan manik-manik kaca dan batu (Adhyatman, 1993: 27-28). Situs lain di Sumatra bagian selatan adalah di sekitar Candi Astano (Soekatno, 1986), di Muara Jambi, Provinsi Jambi, yang pada penggalian arkeologis tahun 1978 menghasilkan manik-manik batu, terakota (tanah liat), dan kaca. 
Di wilayah Jawa Barat pernah ditemukan manik-manik di situs Cibuaya (Kabupaten Karawang) yang diperkirakan berasal dari abad ke-7 Masehi. Di Cibuaya ditemukan manikmanik dari bahan batuan, kaca, dan karnelian. Situs Batu Jaya, terletak tidak jauh dari Cibuaya, menghasilkan manik-manik yang panjang dan manikmanik yang berlubang tiga (Adhyatman, 1993).

Dataran Dieng merupakan kompleks percandian dari agama Hindu yang berasal dari abad ke-89 Masehi. Di antara candi-candi di Dieng ini ditemukan manik-manik dari batu, logam, amber, dan kaca (berwarna kuning, merah, hitam, dan coklat). Di dalam koleksi Museum Nasional Jakarta juga terdapat manikmanik yang berasal dari sekitar Candi Gedong Songo yang berasal dari abad ke-9 hingga10 Masehi dan temuan dari Solo (Adhyatman, 1993).

Pada masa klasik abad ke-5 hingga 15 Masehi, manik-manik digunakan dalam upacara keagamaan, sebagai perhiasan. Beberapa arca di Jawa Timur, yang diperkirakan dari masa Majapahit, digambarkan menggunakan kalung dari manikmanik. Begitu pula pada relief di Candi Borobudur, juga ada penggambaran seorang wanita yang menggunakan perhiasan manik-manik.

Pada masa Islam, manik-manik ditemukan di Tri Donorejo (Demak, Jawa Tengah), Bukit Patenggeng (Subang, Jawa Barat), dan Banten. Manik-manik dari ketiga situs ini dibuat dari tanah liat, batu pasir, batu mulia, kaca, karnelien, dan kuarsa. Dalam periode Islam hasil produksi manikmanik dari luar Indonesia seperti Afrika, Lebanon, Siria, Jasirah Arab, Parsi, Pakistan, India, dan Asia Tenggara meningkat tajam. Manik-manik ini diketahui menjadi bahan perdagangan yang utama di Nusantara.

Faktanya

menunjukkan bagaimana manusia menempatkan manik-manik dalam berbagai sisi kehidupannya, seperti antara lain: manik-manik sebagai benda keramat atau jimat (aspek kosmologis yang memandang manik-manik dari segi falsafah kesemestaan, karena manikmanik dianggap mengandung daya kosmik), manik - manik sebagai benda bumi/ pertambangan (aspek geologis) yang eksotik dan unik (proses evolusi bumi menghasilkan sejumlah mineral beraneka warna dan beragam serat yang dapat digunakan sebagai bahan untuk pembuatan manik - manik), manik-manik sebagai jenis bebatuan yang khas dari suatu wilayah tertentu dan kemudian juga menyebar ke berbagai penjuru dunia (aspek geografis), manik-manik sebagai benda budaya yang dipakai oleh berbagai suku bangsa di dunia, diterapkan dalam berbagai tradisi dan ritual kehidupan dan keagamaannya, sebagai busana atau asesorinya, sebagai lambang status tatanan kemasyarakatannya (aspek antropologis, sosiologis), manik-manik sebagai media pemujaan dan persembahan, sebagai penolak bala (aspek kepercayaan/mistik/ magis), manik-manik sebagai benda yang dicari/diburu dari waktu ke waktu (aspek sejarah), dalam perkembangannya, manik-manik tidak terbatas pada benda unsur alami yang asli (God made) seperti bebatuan, kerang, dan organik lainnya, tetapi juga, dibuat dari bahan olahan seperti kaca, dan logam.

Variabilitas Bahan, Wujud, dan Jenis
Manik-manik dapat dibedakan
atas dasar (a) bahan dan (b) wujudnya.
Kemudian dari segi bahan dapat 
dikelompokkan menjadi (i)manik-manik yang menggunakan bahan-bahan alamiah, misalnya tulang, gading, gigigeligi, batu, kayu, mutiara, dan bijibijian, serta (ii) bahan-bahan olahan misalnya kaca, logam mulia, atom, dan plastik. Oleh karena perbedaan bahan inilah manik-manik mempunyai tingkat keawetan yang berbeda. Ada manikmanik yang mudah hancur, seperti manik-manik yang dibuat dari biji-bijian, dan dari kayu. Ada pula manik-manik yang kuat, terutama yang dirbuat dari tulang, gading, batu, logam, dan kaca.

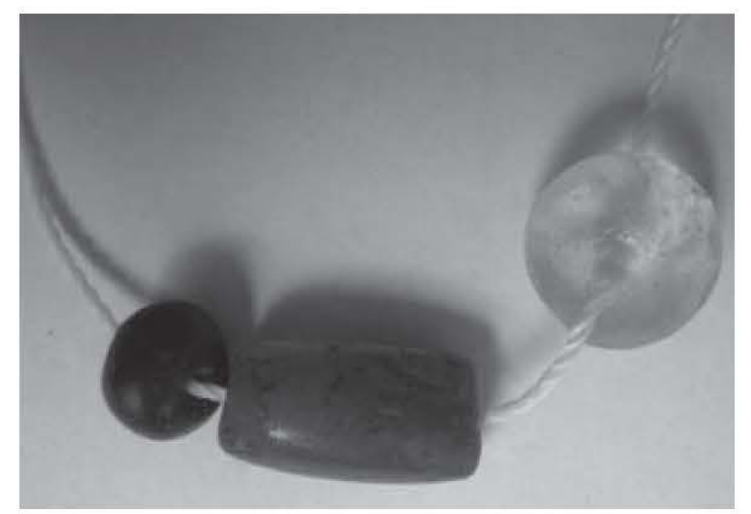

Gambar 2. Manik kaca biru, kornelien, dan kuarsa (rock crystal) (dokumentasi Nasruddin)

Wujud manik-manik mencakup (a) bentuk, (b) warna, dan (c) kehalusan. Dari segi bentuk, ada manik-manik yang bulat, oval, dan persegi. Manikmanik dengan bentuk ini ada yang tebal, ada yang pipih. Warnanya juga bermacam-macam, tetapi biasanya berkaitan dengan terang-gelapnya bahan manik-manik. Ada manik-manik yang dibuat dari jenis batu-batuan yang terang, yang tembus cahaya, yang membuatnya tampak lebih berkilau, lebih indah daripada manik-manik yang gelap. Manik-manik dari batu terang ini ada berbagai macam warnanya. Warna yang sangat banyak dijumpai adalah putih, ungu, hijau, merah, oranye dan hitam. Warna-warna tertentu dianggap memiliki makna dan manfaat tertentu, sehingga seringkali banyak dicari para penggemar manik di Indonesia.

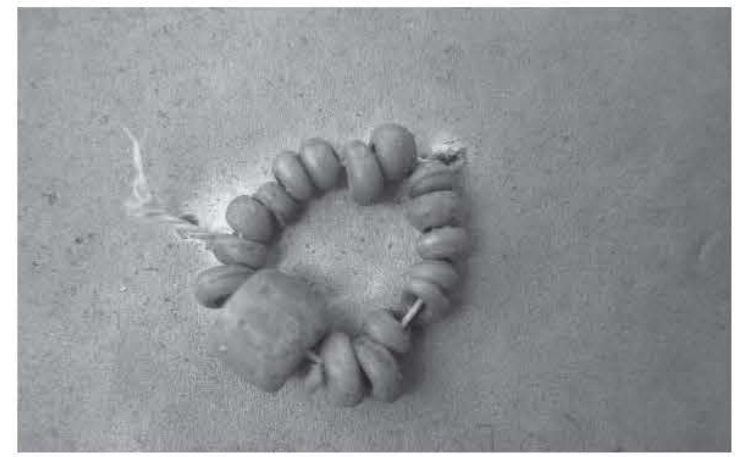

Gambar 3. Manik-manik coil bead mirip manik-manik mutisala (dokumentasi Nasruddin)

Manik-manik dari batuan, termasuk dalam kategori batu mulia memiliki beragam warna yang sangat indah serta tingkat kekerasan yang tinggi hingga 7 skala Moh's. Jenis bahan batuan untuk manik-manik batu yang dapat dikenali meliputi amber, garnet, jade, corundum, kuarsa; kecubung (amethyst), kalsedon, akik (agate), karnelian (carnelian), oniks (onyx), dan merjan (coral). Salah satu ciri utama yang membedakan manikmanik batu dengan manik kaca, terletak pada bentuk pelubangannya. Ada dua tipe pelubangan yang dapat dikenali, yaitu pelubangan satu sisi dan dua sisi dengan menggunakan mata bor dari batuan yang lebih tinggi kekerasannya seperti jasper, rijang (chert) dan intan. Berdasarkan bukti-bukti tersebut di atas dapat diketahui bahwa manik-manik yang dikenal dewasa ini memiliki cikalbakal dari bahan alamiah yang sangat sederhana sesuai dengan kemampuan berpikir manusia masa itu.

Sampai saat ini, dari beberapa sumber literatur yang dijadikan acuan, pembuatan awal manik-manik kaca mulai terjadi ketika manusia telah menguasai penuangan logam termasuk kaca. Kaca biasanya terdiri atas campuran unsur kuarsa, soda, potassium atau nitrat dengan sedikit kapur. Ada juga manik-kaca yang mengandung timah hitam atau perunggu. Tempat awal pembuatan 
manik-manik, baik kaca maupun batu diketahui berada di Mesopotamia dan Mesir dengan pertanggalan antara 6500-2500 SM. Manik-manik ini kemudian didistribusikan melalui perdagangan ke berbagai tempat di Laut Tengah dan Asia Barat hingga ke Eropa. Keterangan lain menyebutkan pula bahwa orang Romawi-lah yang kemudian diwarisi kemampuan atas industri manik-manik Tunisia dan Mesir yang diperdagangkan ke Timur Jauh (Francis, 1989:11-23).

Sementara itu, baik manikmanik kaca maupun batu yang beredar di Indonesia berasal dari India, khususnya dari India Utara, setidaknya diperkirakan dari sekitar masa paleometalik (periode logam awal) antara abad kedua SM ( \pm 200 SM - 400 M). Daerah pembuatan manik-manik batu seperti kuarsa, agate, kalsedon, kornalian dan oniks, yang juga penting untuk diketahui yaitu, Cambay di Gujarat (India Barat), dan Arikamedu (kini: Pondicherry) di daerah pantai India Tenggara, yang disebut-sebut para ahli sebagai pemasok atau produsen manik untuk pasar Eropa, Afrika, dan Asia Tenggara (Adhyatman, 1993: 11-15).

Situs-situs penyimpan atau memiliki temuan manik-manik kaca dan sedikit batu pada umumnya ditemukan pada situs kubur prasejarah dan situs megalitik antara lain Gilimanuk Bali, Plawangan-Rembang, Anyer, pantai utara Jawa Barat (Bekasi dan Karawang), Jawa Timur (Besuki, Tulung Agung, dan Besuki-Bondowoso), dan banyak tempat lainnya di luar Jawa seperti, Liang Bua (Flores), Timor Barat, Lengkeka, Poso (Sulawesi Tengah) (Panggabean, 1983).

Manik-manik batu yang selama ini dijumpai dari situs-situs kubur di atas terdiri atas jenis batu yang memiliki kekerasan cukup tinggi seperti kalsedon, kwarsa, ametis dengan warna ungu dan jenis lainnya dari batu agate (akik). Bentuk manikmanik batu ini meliputi bulat dempak, sebagian dengan bentuk kerucut ganda dan persegi. Sedangkan manikmanik berbahan kaca merupakan temuan cukup besar dan lebih variatif dari segi warna antara lain dengan warna merah bata dan lebih popular dengan sebutan manik 'mutisalah', tapi terdapat juga warna yang lebih terang seperi orange yang semuanya tidak tembus pandang atau bersifat opaqe. Warna lain terdapat biru tua, kuning, hijau yang semuanya berwarna tembus pandang (translucent). Sementara dari segi bentuk dapat disebutkan antara lain tipe selinder dengan bentuk paling dominan, diikuti bentuk bulat dempak dan bentuk lainnya; tablet, dan berleher. Pada temuan manikmanik kaca ini diperoleh informasi pertanggalan melalui analisis konteks seperti yang pernah dilakukan dari situs Gilimanuk yaitu diketahui berkisar \pm 500 SM-100 M.

Dapat dikatakan bahwa secara kuantitas manik-manik yang beredar di Indonesia sangat banyak, tidak hanya segi jumlah tetapi berdasarkan atas klasifikasi periodisasi, jenis, tipe dan bentuk sangat beragam, termasuk asal-usul manik-manik itu didatangkan (import) diketahui berasal dari berbagai tempat seperti India, Asia Barat, Cina dan Eropa. Namun bukan berarti seluruhnya berasal dari luar Indonesia, karena sejumlah tempat atau situs diketahui memiliki indikasi adanya jejak industri manik-manik pernah berlangsung di sini. Tempattempat itu terletak di Situs Kambang Unglen, Palembang yang diperkirakan memproduksi manik-manik kaca monokrom yang berlangsung antara abad ke-7 hingga $9 \mathrm{M}$. 
Situs Lobu Tua, Barus diduga kuat pernah memproduksi manik-manik kaca, karena hasil penelitian arkeologi antara Perancis dan Indonesia pada tahun 1995 dan 1996 ditemukan sejumlah fragmen bahan kaca dan manik-manik. Berdasarkan tinjauan atas temuan-temuan itu, menunjukkan bahwa didatangkan dari dua daerah asal, yaitu Iran dan Mesopotamia, lalu selanjutnya bahan-bahan kaca itu dikerjakan untuk keperluan manikmanik maupun benda-benda kaca lainnya. Tafsiran penghunian Lobu Tua sebagai tempat atau lokasi penghasil kaca dan manik-manik yaitu antara fase abad ke-9 hingga $10 \mathrm{M}$. Jambi juga memiliki indikasi pembuat manik pada sekitar abad ke-14 M. Tempat lainnya yang diduga pula pembuat manik-manik yaitu; Situs Kemiling, Lampung Utara dan situs Banten yang diperkiran sekitar abad ke-13 M.

\section{Manik Batu Mulia}

Bahan batuan yang dijadikan manik-manik meliputi amber, garnet, jade, corundum, kuarsa, kecubung (amethyst), kalsedon, akik (agate), kamelian (Camelian), oniks (onyx), dan merjan (coral).

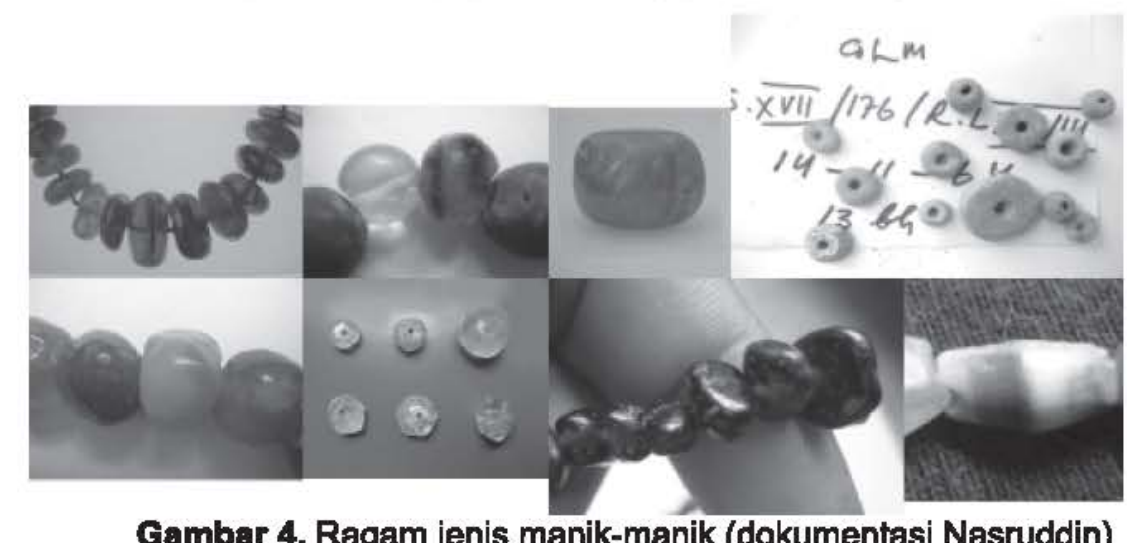

\section{Karnelian}

Manik batu paling popular yaitu kamelian atau juga disebut kamelia. Warnanya yang sangat menonjol adalah warna merah-kecoklatan. Manik-manik batu kamelian dikenal pula sebagai manik dalam kelompok manik tertua diantara jenis manik batu lainnya. Manik kornalien mungkin telah mulai beredar di Indonesia pada akhir masa prasejarah, karena di beberapa situs perundagian dan kubur megalitik sering ditemukan manik-manik kamelian, khususnya bentuk bulat dempak sebagai bekal kubur. Tempat- tempat penemuan manik kornalien seperti situs Gilimanuk, Plawangan, Karawang dan beberapa tempat di Jawa Barat, Lampung, Muara Jambi, dan Jawa Timur.

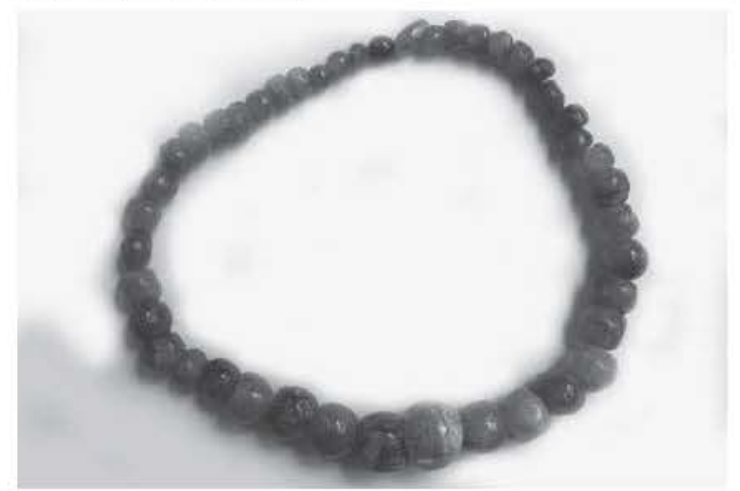

Gambar 5. Manik-manik komalian (dokumentasi Nasruddin) 


\section{Amber}

Suatu jenis batuan fosil getah atau damar pohon pinus (Pinus Succinifera) yang hidup di sekitar 30 juta tahun lalu. Oleh karena itu, amber akan mengeluarkan bau damar yang harum kalau ditusuk dengan jarum panas. Amber asli juga dapat mengambang di larutan jenuh air garam serta memiliki daya konduksi panas yang rendah. Di samping itu, amber juga akan menampakkan polapola tekanan internal yang khas jika dilihat di bawah polariskop (Budiman, 2004: 4).

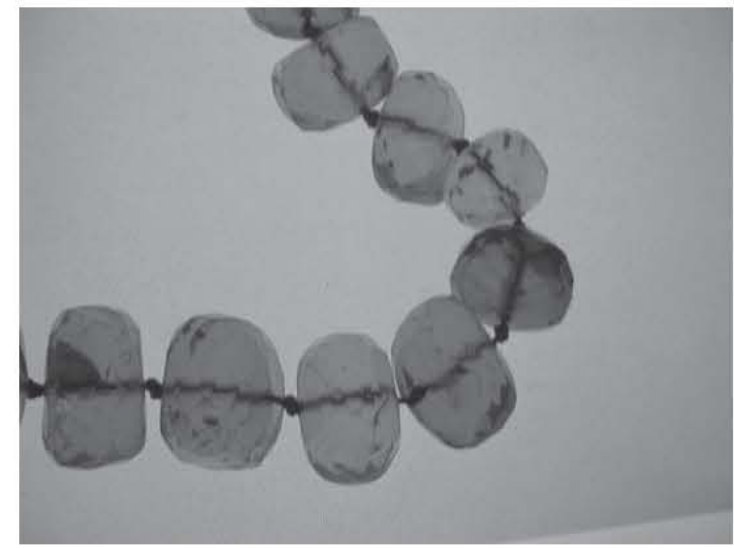

Gambar 6. Manik-manik amber (dokumentasi Nasrudddin)

Manik amber sering mengecohkan peneliti, karena sangat mirip dengan manik kaca. Biasanya memiliki warna kekuningan, kecoklatan, atau kemerahan sampai warna hitam yang disebut dengan jet. Di Indonesia manik-manik jenis ini termasuk sangat langka ditemukan. Para penggemar permata sangat menyukai batu amber ini, khususnya yang mengandung fosil serangga, karena dapat mencapai harga yang sangat tinggi.

\section{Garnet}

$\begin{array}{lll}\text { Batuan ini mirip dengan } & \begin{array}{l}\text { ini } \\ \text { kecubung }\end{array} \text { (amethyst) } & \text { dengan }\end{array}$ perpaduan warna merah keunguan yang gelap. Akan tetapi, batu ini dapat beragam warna, kecuali biru. Di kalangan penggemar permata, garnet

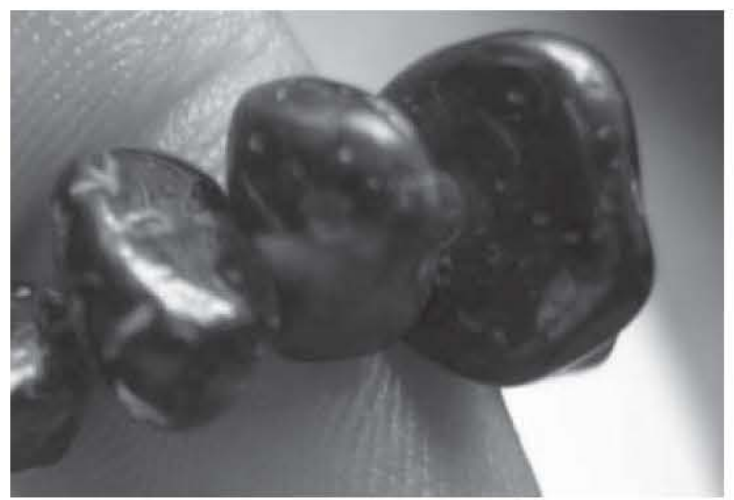

Gambar 7. Manik-manik batuan garnet (dokumentasi Nasruddin)

lebih dikenal dengan nama 'biduri delima'. Sumber penghasil garnet antara lain Sri Langka, India, Myanmar, Cina, Arab, dan Madagaskar. Manikmanik garnet memiliki bentuk bulat dempak (oblate) dan beberapa bentuk tak beraturan (alamiah). Batuan garnet memiliki juga beberapa nama lain yang merupakan campuran atas varitasvaritas utama dengan perbedaan pada komposisinya yang spesifik seperti pirop, alamandit, rodolit, spesartit, dan andralit.

\section{Kuarsa (Quartz)}

Manik-manik kuarsa merupakan temuan terbanyak di Indonesia dengan berbagai bentuk dan ukuran. Jenis yang lazim dijumpai di Situs Gilimanuk dan Batu Jaya, Karawang yaitu jenis kecubung, agate, kristal bening (putih dan berkabut). Manik batu yang umum ditemukan di Situs Batu Jaya meliputi jenis agate dan kristal putih. Dapat dikatakan bahwa manik bahan kuarsa dengan berbagai jenisnya ditemukan tersebar luas di Nusantara.

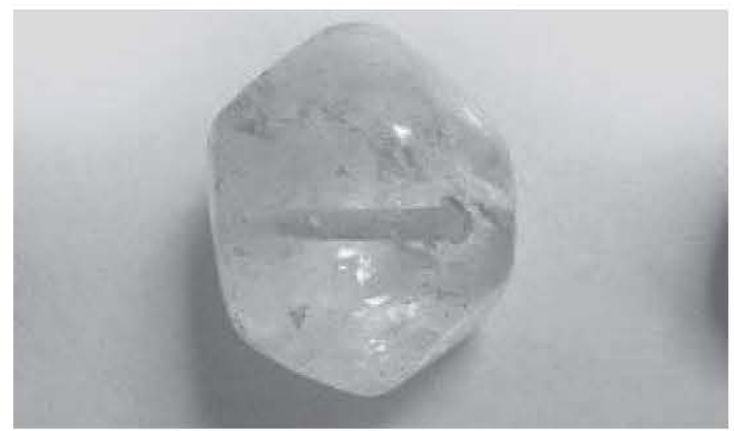

Gambar 8. Manik-manik batu kuarsa (dokumentasi Nasruddin) 
Kuarsa adalah satu-satunya keluarga mineral paling melimpah di kerak bumi, sehingga terdapat pada hampir setiap lingkungan geologis di bumi. Hampir setiap tipe batuan terdiri atas mineral kuarsa, bahkan sering kali kuarsa merupakan mineral primer (>98 $\%)$. Spektrum warna mineral kuarsa sangatlah beraneka, meskipun sejauh ini kristal bening adalah yang paling umum, lalu putih atau berkabut, ungu, merah jambu, coklat atau bahkan warna-warni (Simon dan Schuster's, 1979:244).

Berkenaan dengan manikmanik kaca yang dikelompokan dalam monokrom, manik-manik ini memiliki ciri teknologi yang lebih praktis yaitu dibuat dengan teknik tarik (drawn technique), berukuran kecil dengan sifat warna yang kusam (opaqe). Manik-manik jenis ini banyak tersebar di Asia Tenggara umumnya, termasuk Indonesia. Beberapa kalangan termasuk penulis menduga bahwa perkembangan awal pembuatan manik-manik kaca bermula dari jenis ini atau bisa disebut manik kaca tertua yang pertama diperkenalkan dan dipasarkan ke sejumlah tempat di Asia Tenggara. Banyak peneliti yang membahas manik-manik tersebut dan sebagian diantaranya memberi istilah yang berbeda. Van der Sleen misalnya menyebut manik-manik ini, baik yang dibuat melalui teknik tarik (drawn) mapun manik-manik teknik gulung (wound) sebagai Trade Wind Beads. Istilah ini digunakan juga pada manik-manik kaca yang mengandung uranium.

Perbedaan antara manik-manik monokrom yang dibuat dengan teknik tarik dan gulung begitu nyata dan dapat diamati secara kasat mata, sehingga kedua jenis manik-manik tersebut tidak dapat digolongkan ke dalam kelompok yang sama satu dengan lainnya. Sumber asal pembuatannya pun berbeda. Jadi kedua jenis ini harus dilihat secara terpisah. Disebabkan oleh adanya kerancuan pandangan, maka Peter Francis (1989) memperkenalkan nama baru yang dapat menggambarkan manikmanik monokrom yang menggunakan teknik tarik secara lebih baik dan jelas, yaitu Indo-Pacific atau kependekan dari Indo-Pacific Monochrome Drawn Glass Beads (manik-manik kaca monokromatik Indo-Pasifik dengan teknik tarik). Istilah itu mengacu pada distribusi, warna, teknik pembuatan, serta bahan manik-manik Indo-Pacific. Di lain pihak, penyebutan untuk manikmanik teknik gulung adalah manikmanik 'kumparan' seperti pada manik Cina (Chinese coil beads) (Francis, 1989).

Manik-manik monokrom terbatas hanya satu warna untuk satu jenis manik, tanpa adanya kombinasi warna satu dengan lainnya. Jadi manik monokrom hanya meliputi merah bata kusam, kuning, biru gelap, dan hijau. Khusus untuk warna merah bata, jingga, merah kecoklatan atau oranye, dipopulerkan dengan nama mutisalah oleh Van der Sleen. Istilah ini awalnya berkembang di dalam masyarakat Nusa Tenggara Timur sebagai pengguna manik-manik tersebut. Beberapa peneliti terjebak dengan istilah mutisalah, karena menganggap manik-manik ini memiliki kategori tersendiri yang membedakan dengan manik-manik kaca yang telah disinggung sebelumnya sebagai IndoPasific Monochrome beads. Padahal, sesungguhnya mutisalah adalah kelompok manik kaca Indo-Pasifik, tanpa ciri perbedaan dengan manik kaca lainnya, kecuali pada unsur warna. 


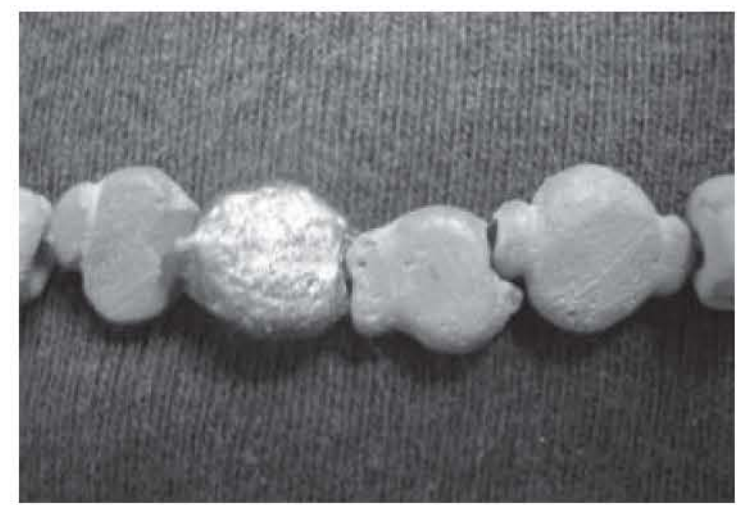

Gambar 9. Manik-manik kaca monokrom (dokumentasi Nasruddin)

Kelangsungan penggunaan manik-manik kaca monokrom cukup panjang hingga abad ke-17 Masehi. Kemudian perlahan-lahan manikmanik kaca monokrom tergantikan oleh manik-manik mosaik yang memiliki pilihan warna dan motif yang lebih beragam, yaitumanik-manik kaca polikrom. Walaupun pusat-pusat produksi manik Indo-Pasifik mulai menghilang, tetapi kemudian manikmanik Cina mencoba menduplikasi manik monokrom dengan peniruan bentuk dan warna, terutama pada jenis warna opaqe merah bata dengan bentuk bulat dempak yang banyak didistribusikan di AsiaTenggara, termasuk Indonesia.

\section{Manik-Manik Polikrom}

Manik-manik polikrom atau biasa juga disebut mozaik dengan variasi warna dan motif yang beragam melengkapi distribusi manik-manik kaca di kawasan Asia Tenggara. Menurut para ahli, manik-manik polikrom yang beredar di Nusantara pada abad sejarah (sekitar abad ke-5 Masehi), hingga masa kolonial, yaitu berasal dari beberapa tempat antara lain India Utara, Asia Barat melalui jalur sutra, dan yang cukup dominan adalah Cina. Ketika ekspansi orang-orang Eropa pada sekitar abad ke-16 hingga 17 Masehi, perdagangan manikmanik kaca di Nusantara mencapai puncaknya untuk ditukarkan dalam bentuk barter dengan komoditi rempah dan kekayaan alam lainnya.

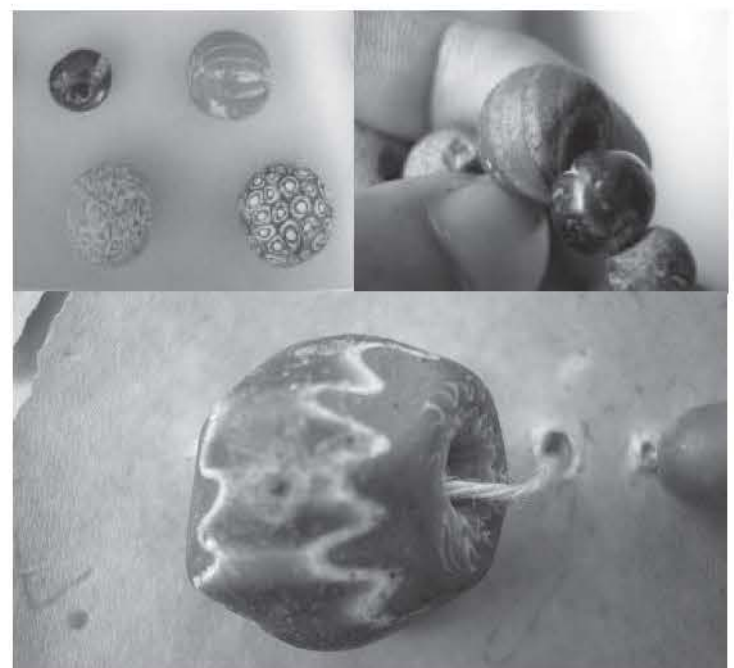

Gambar 10. Manik-manik kaca polikrom, manikmanik pelangi Mesir, manik-manik Venesia (dokumentasi Nasruddin)

Begitu beragamnya jenis manikmanik baik dari segi bentuk, warna dan bahan, maupun dari segi teknologi pembuatan, namun memahami manikmanik sebagai data arkeologi, tidak sekedar secara lahiriah saja, tetapi perlu pula diungkap tentang prosesnya sebagai komoditi yang memiliki nilai distribusi sangat luas atau dapat dikatakan sama dengan benda-benda keramik. Menurut hemat penulis diperlukan berbagai analisis, terutama analisi laboratorium untuk menjawab asal-usul suatu manik-manik. 


\section{PENUTUP}

Manik-manik dengan segala keragaman jenis, bentuk dan ukuran yang relatif kecil, memiliki nilai yang amat dalam dan sekaligus mengandung berbagai informasi tentang sejarah masa lampau. Kajian manik-manik dapat menggambarkan latar kehidupan manusia, baik yang terkait tentang ide atau gagasan, teknologi, apresiasi estetika (seni), maupun kepercayaan magis-religius.

Dalam mempelajari manikmanik, tidak hanya pemahaman persebaran manusia di masa lalu yang diperoleh, tetapi diperoleh pula peta perdagangan dan lalu lintas manusia antarsatu tempat ke tempat lainnya yang saling berjauhan jaraknya hingga melintasi negara dan benua.

Masyarakat tradisional di Kalimantan, Nusa Tenggara, Sulawesi, dan Sumatra, baik yang berdiam di pedalaman maupun pesisir pantai di Nusantara, mereka terbiasa menggunakan manik-manik sebagai perhiasan, alat upacara, pakaian, tongkat, ataupun fungsi lainnya. Masyarakat tersebut bangga memakai manik-manik sebagai bagian tradisi warisan leluhurnya. Masyarakat tradisional yang masih menggunakan dan memelihara manik-manik sebagai bagian dari tradisi mereka merupakan sumber terbaik bagi studi arkeologi melalui pendekatan analogi-etnografi.

Persebaran temuan manikmanik terus meningkat di era neolitik yang didistribusikan oleh kelompok manusia Austronesia yang bermigrasi ke Nusantara, hingga makin meluas memasuki abad sejarah sebagai komoditi dalam perdagangan di Nusantara. Perjalanan panjang manikmanik ini sebagai karya dan kreasi budaya memang sangat dinamis dan mengikuti gerak perkembangan zaman, serta tidak pernah putus ataupun berhenti, selalu dibutuhkan dan diperlukan serta digemari dalam berbagai aspek kehidupan manusia hingga dewasa ini. Manik-manik tidak hanya mempunyai nilai yang dapat dibaca melalui penampilan luar (outerappearance) bagi pemakainya, tetapi nilai yang juga menyiratkan makna dari dalam (inner value) yang dapat dirasakan melalui penginderaan batin. Perpaduan antara keindahan artistik-estetik dan makna inilah yang menjadikan manik-manik secara universal menarik sepanjang masa, sehingga manik-manik digunakan dalam berbagai kegiatan hidup manusia di mana saja. 


\section{KEPUSTAKAAN}

Adhyatman, Sumarah, dan Redjeki Arifin. 1993. Manik-manik di Indonesia. Jakarta: Djambatan.

Budiman, Kris. 2004. Semata Permata: Pengantar tentang Keberagaman Permata. Yogyakarta: Buku Baik.

Encyclopedia Americana. 1973. Beads. Vol. 3: 394.

Francis, Peter Jr. 1989. Beads and the Bead Trade in Souteast Asia. Contributions of the Center for Bead Research 4. New York: Lake Placid.

Hoop, A. N. J. Th, a Th. van der. 1932. Megalithic Remains in South Sumatera, Translated by M. Shirlaw, Sutphen.

Panggabean, Indraningsih, Joyce R. 1981. "Manik-manik di Indonesia Situs Pasir Angin". Amerta 4. Jakarta: Pusat Penelitian Arkeologi Nasional.

Panggabean, Indraningsih, Joyce R. 1977. "Manik-manik dari Situs Pasir Angin dan Gilimanuk". Skripsi. Jurusan Arkeologi, Fakultas Sastra, Universitas Indonesia.

Panggabean, Indraningsih, Joyce R. 1983. "Manik-manik Mutisala dari beberapa situs di Indonesia", REHPA I. Jakarta: Puslit Arkenas. HIm. 177-125.

Panggabean, Indraningsih, Joyce R. 1985a. "Manik-manik dari Kubur Peti Batu di Kidangan dan Kawenga, Bojonegoro", REHPA. Jakarta: Puslit Arkenas. HIm. 41-54.

Panggabean, Indraningsih, Joyce R. 1985b. "Research on Prehistoric Beads in Indonesia”, IPPA, 6. HIm. 133-141.

Shiffer. 1976. Behavioral Archeology. New York, San Francisco, London: Academic Press. HIm. 27-28.

Simon dan Schuster's. 1978. Guide to Rocks and Minerals. The American Museum of Natural History.

Soejono R. P. (ed).1984. Sejarah Nasional Indonesia I, Departemen Pendidikan dan Kebudayaan. Jakarta: Balai Pustaka.

Soekatno, Endang Sh. 1986. "Analisis Manik-manik dari Situs Muara Jambi”, Rehpa III.

Sukendar, Haris. 1975. "Temuan Manik-manik Prasejarah di Palembang", Buletin Yaperna, No. 6, 11 April. HIm. 57-69.

Rouse, Irving. 1971. "The Classification of Artifacts in Archaeology", dalam James Deetz (ed.), Man's Imprint the Past. Boston, Toronto: Little, Brown and Company. 